\section{Further comments on the systematic status of Lygosoma vosmaerii (Gray, 1839)}

\section{Raju Vyas}

505, Krishnadeep Tower, Mission Road, Fatehgunj, Vadodara, Gujarat, India

Email: razoovyas@ hotmail.com

The Vosmer's Writhing Skink Lygosoma vosmaerii was described as Hagria vosmaerii by Gray (1839), as is presently accepted, with Java as type locality based on the specimen sent to him by M. Bibron (Gray 1874). Dumeril \& Bibron (1839) provided a full description of the same specimen collected by M. Lamarre-Piquot from Bengal Province (with out any specific locality) as Campsodactylus lamarrei. Later, Boulenger (1887) allocated it to the genus Lygosoma and assigned 'Deccan' as its type locality and finally Boulenger (1890) considered it as synonymy.

After the description, there was no new information on the species, but subsequent herpetologists accepted it as distinct taxa (Smith 1935; Sarma 2002), except Vyas (2001) who questioned its taxonomic status on the basis of an anomalous specimen of L. lineata. Also, Das (2003) did not mention it in the list of reptiles of India. But recent published note on 'Rediscovery of Vosmer's Writhing Skink Lygosoma vosmaerii (Gray, 1839) (Reptilia: Scincidae) with a note on its taxonomy' by Seetharamaraju et al. (2009) stated that the species' taxonomic status is valid. Here I take the opportunity to comment on the systematic status of the L. vosmerii (Gray 1839) and address it as a debatable subject.

Seetharamaraju et al. (2009) were able to collect a second specimen (NHM.OU.REP.1-2009) of the species, after 170 years of description, and there was no doubt in its identification. But Boulenger (1890) mentioned it as an anomalous specimen and Vyas (2001 \& 2009), treated the L. vosmaerii as an anomalous specimen of $L$. lineata on the basis of a specimen from Gujarat, which has five fingers in right forelimb. Also, it is a fact, that this was an anomalous specimen of $L$. lineata, as it was found along with other few live specimens of $L$. lineata. On that ground, Vyas (2001) considered and treated anomalous specimen as a species belonging to $L$. lineata, instead of an anomalous specimen of L. vosmaerii (Gray, 1839).

Therefore, Vyas' (2001) proposal is not rejectable at this juncture, however, the present rediscovery of $L$. vosmerii (Seetharamaraju et al. 2009) considerably supports the validity of the taxon (albeit on the basis of a single specimen). But still the taxonomic status of $L$. vosmerii is questionable on the basis of the voucher (BNHM 1453) from Velavadar National Park, Bhavanagar District, Gujarat (Vyas 2001) and this clearly suggests further debate on the taxonomic status of L. vosmaerii (Gray, 1839).

Therefore I personally propose and believe that the present taxonomic status of $L$. vosmerii is still uncertain/ pending and needs further investigation of the area of Jaggayapet, Krishna District, Andhra Pradesh for establishing the systematic status of the species by collection and examination of a series of specimens; for it can be revealed by genetic studies only.

\section{References}

Boulenger, G.A. (1887). Catalogue of the Lizards in the British Museum (Nat. Hist.) III. Lacertidae, Gerrhosauridae, Scincidae, Anelytropsidae, Dibamidae, Chamaeleontidae. Taylor and Francis, London, 575pp.

Boulenger, G.A. (1890). The Fauna of British India, including Ceylon and Burma. Reptilia and Batrachia. Taylor and Francis, London. xviii + 541pp.

Das, I. (2003). Growth of knowledge on the reptiles of India, with an introduction to systematics, Taxonomy and Nomenclature. Journal of the Bombay Natural History Society 100(2 \& 3): 446-501.

Duméril, A.M.C. \& G. Bibron (1839). Erptologie generale ou histoirie naturelle complete des reptiles. vol. 5. 854pp.

Gray, J.E. (1839). Catalogue of the slender- tongued saurians, with descriptions of many new genera and species. Annals and Magazines of Natural History 2: 331-337.

Gray, G.R. (1874). Reptiles, pp1-8. In: Richardson, J. \& J.E. Gray (eds.) The zoology of the voyage of H.M.S. Erebus \& Terror: under the command of Captain Sir James Clark Ross, during the years 1839 to 1843. Vol. II. Reptiles, Fishes, Crustacea, Insects and Mollusca. E.W. Janson, London, 221pp+ plates.

Seetharamaraju, M., R. Sreekar, C. Srinivasulu, Bhargavi Srinivasulu, Harpreet Kaur \& P. Venkateshwarlu (2009). Rediscovery of Vosmer's Writhing Skink Lygosoma vosmaerii (Gray, 1839) (Reptilia: Scincidae) with a note on its taxonomy. Journal of Threatened Taxa 1(12): 624-626.

Vyas, R. (2001). Notes on the distribution of Lygosoma lineata (Gray, $1839)$ and comments on the systematic status of Lygosoma vosmaerii (Gray, 1839). Hamadryad 26(2): 360-361.

Vyas, R. (2009). Notes on the distribution and natural history of an endemic skink from India: Lygosoma lineata (Gray, 1839). Sauria 31(1):45-50.

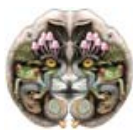

Date of publication (online): 26 January 2010

Date of publication (print): 26 January 2010

ISSN 0974-7907 (online) | 0974-7893 (print)

Manuscript details:

Ms \# 02377

Received 30 December 2009

Citation: Vyas, R. (2010). Further comments on the systematic status of Lygosoma vosmaerii (Gray, 1839). Journal of Threatened Taxa 2(1): 674.

Copyright: (C) Raju Vyas 2010. Creative Commons Attribution 3.0 Unported License. JoTT allows unrestricted use of this article in any medium for nonprofit purposes, reproduction and distribution by providing adequate credit to the authors and the source of publication. 